INTERNATIONAL ELECTRONIC JOURNAL OF MATHEMATICS EDUCATION
IEJME
OPEN ACCESS

\title{
Mathematics Teachers' Perception of Using Social Media in Their Teaching in Tabuk, Saudi Arabia
}

\author{
Abdullah Suliman Albalawi ${ }^{\mathrm{a}}$ \\ aUniversity of Tabuk, SAUDI ARABIA
}

\begin{abstract}
The purpose of this study was to discover the status of social media use among mathematics teachers in the classroom, determine their perception of using social media in teaching, and to discover the differences among participants' responses based on gender, experience, and the level at which they teach. A survey was designed with two domains: the usability of social media, and the importance of using social media. The sample for the study was 142 mathematics teachers (82 male and 60 female) teaching at different schools in Tabuk, Saudi Arabia. The findings refer to moderate use of social media among teachers, who sometimes use it in their teaching with no specific target; however, they believe in the importance of using social media in their teaching and perceive it positively. Moreover, findings revealed that in both domains, the participants means differ significantly, favoring female teachers over male teachers; however, there was no significant difference among participants in either domain in relation to experience or level of school taught.
\end{abstract}

KEYWORDS

social network, social media, mathematics teaching, mobile

learning
ARTICLE HISTORY

Received 11 January 2017

Revised 28 April 2017

Accepted 4 May 2017

\section{Introduction}

During the past few decades, many learning theories have come to light with a new hypothesis that affects the teaching process, due to its connection between the classroom's instruction and the real life. One of the new theories was connectivism, a concept created by Siemens and Downes. Connectivism explains how Internet technologies have created opportunities for people to learn and share information across the World Wide Web and exchange information with others. Using technology gives students the opportunity to facilitate learning and exchange information. According to Siemens (2005), connectivism emphasizes providing specialized information sets, which enable us to gain more knowledge through clear guidance of how to use the technology to be more 
efficient in learning.. One of the key components of connectivism is that the process of learning can be done through a specialized online network. Moreover, the role of the teacher becomes that of a supporter and guide for students as they learn new information. Students can share results and the new information with their peers in the online community (Downes, 2010).

The use of Internet and technology in learning and teaching has become a popular concept in a modern, technology-based society. While many research studies have reported beneficial use of new technologies in educational sectors, the viability use of new technology and its applications in the school setting as an option for e-learning is still very limited in most university disciplines for both learners and teachers (Hsueh, 2011). Although laptops for instance are popular in our routines and lives, they are not practical enough in terms of consistency with developed technology nowadays to be used by teachers and learners. To address this issue, much research has been conducted to examine the application of technology in the process of teaching and learning. The most commonly implemented applications are those accessible on desktop computers, the Internet, and media, including programs such as PowerPoint, Word, Excel and other programs, both software and hardware. In the context of these changes, mobile phones can be used as a useful teaching device, providing teachers and learners with modern and automated techniques for achieving an educational target (Boyle, 2013). Mobile phones, compared to larger technological devices, are an affordable investment for teaching and learning mathematics. Also, the use of mobile phones may provide a supportive and friendly teaching environment that can enhance and facilitate the educational process when correlated it to the repaid technology in the society Recent technology, including cell phones, can make things easy and education-friendly by making real and virtual communication available any time and in any place (Jee, 2011). The high-tech features of new mobile devices, for instance its application that rapidly spread and easy to download through e- storages, can have a lot to do with teaching and learning for many scientific fields, especially mathematics. Cell phones are private personal devices, but can also be effective educational devices. Kukulska-Hulme, A., Traxler, J.,\& Pettit, J. (2007) Argue that learning activity designers need to consider the characteristics of mobile learning. Thus, using cell phones in the education process provides college students the opportunity to connect with any device and any person at any time and exchange information. For instance, mobile phones contain program applications that science education, particularly mathematics, has recently been seeking for pedagogical purposes. These features may relate to options such as accessibility, flexibility, and mobility (Jee, 2011). Cao and Hong (2011) reported in their findings that there are four antecedent factors for social media use in teaching: (1) faculty's personal use of social media and their readiness to use it; (2) external pressure on teachers from peers, supervisors, students, and employers to use social media; (3) expected benefits; and (4) perceived risks. Moreover, they reported two factors that are important in assessing the consequences of social media use in teaching: perceived student satisfaction and student learning outcomes.

Due to students' familiarity with social media use and ease in utilizing it, and due to its influence on education as proved by many studies such as (Cao and Hong (2011); Genossar et al. (2008); Bor (2014); Sim, T., Naidu, D., \& Apparasam, D. (2014); Echenique, Molías, and Bullen (2015) ), it is worth it for 
teachers to think about bringing this technology into the classroom, in order to apply students' love and engagement with social media to the teaching and learning process, and to apply student-centered learning. Many studies about online social networks indicate their ability to engage students, allowing them to communicate more effectively with one another, discuss academic and social matters, engage in rigorous and productive group projects, have the flexibility to learn anytime, and enhance students' creativity. (Baird \& Fisher, 2006; Santovec, 2006; Arieanna, 2007; Hagler, 2013). Moreover, Okoro (2012, 255) has concluded that "electronic media enhance collaborative learning activities, enabling students to engage in ongoing communication with one another in the process of learning. Moreover, effective use of social networking tools in learning environments by faculty can sustain the quality of instructions and skills development in business education." Moreover, in a study done in Kuwit, Alenezi and Almejadi (2013) discovered that most female students at a fundamental education college, especially those majoring in science were interested in using social media in the classroom, particularly Facebook and Twitter, and believed that social media is a resource that provides information and facilitates their communication with teachers and their peers; they were familiar with using such applications. Moreover, concentrating on content creation and sharing, in addition to student engagement, are important aspects that should inform the teaching process As concluded by Jankauskaite (2015), Elkaseh, Wong, \& Fung (2016) in their research in Libya, perceived ease of use and perceived usefulness are important factors for predicting a student's and teacher's behavioral intention to use social networks for e-learning in higher education. Finally, Dawley, L. (2009) noted that new pedagogies are needed to effectively integrate mobile learning into the learning environment.

This research intends to investigate the use of social media applications in teaching mathematics at schools in Tabuk.

\section{Literature Review}

The use of mobile phone applications and technology in an educational setting involves positive complexities that should be taken into account. In this regard, much research has been conducted to investigate the use of social media and computer technology in the teaching and learning process. In a study by Attewell et al. (2003) to explore the use of mobile phones by adult learners for literacy learning, it was found that most of the adult learners felt very excited and interested about the use of cell phones for gaming. They added that they were also excited about technology in the use of solving mathematical equations.

Baran (2014) in his review of 37 researches on mobile learning and networking, he concluded that; 1) the number of articles published has significantly increased over the last five years; 2) there was a scant report of theoretical and conceptual perspectives; 3)participants of these studies were vary in their perceptions, attitudes and usage patterns of mobile learning; 4) mobile learning was reported as mainly beneficial in teacher education contexts; 5) challenges of using mobile learning were reported; 6) integrating mobile learning in teacher education setting was supported. 
Similarly, Lubega et al. (2004) conducted a study to investigate the attitudes of high school students towards mobile phones and learning. This study took place in the United Kingdom. The findings of the study showed that most of the high school students were positive concerning the application of mobile phones for educational purposes. The findings also indicated that the use of mobile applications such as calls, MMS, and SMS for one person or group discussion were very useful. The study recommended that further research be conducted to examine personalized communication and shared information between learners and teachers through the use of mobile phones.

Likewise, Inagaki et al. (2004) conducted a study to examine the use of cellular phones as a tool for communication purposes in Japan. The sample group for the study was comprised of elementary students in Japan. The findings of the research revealed that mobile phones were used by students for learning and communication, including taking pictures and commenting on school bulletin boards, sending emails, and using video calls and other devices for communication. Traxler et al. (2005) in their study showed that the use of mobile phones in learning develops the learner's comprehensive instruction pedagogically.

Furthermore, Wei and Chen (2006) conducted a research study to design an e-book interface for mobile phones that provides learners the option to type their comments onto the text. The findings of the study showed that the e-book interface was very useful for students, specifically for recording questions, comments and getting feedback. In another study, Genossar et al. (2008) indicated that the use of mobile phones in the educational setting enhanced students' ability to accomplish their exercises in the real situations. This was shown by the students' ability to gain awareness of important mathematical in such conditions.

In project funded by the National Science Foundation to investigate catalyzing network expertise, Kim (2011) found that teachers' use of social networks can improve teaching practice by changing formal (grade) and informal (subgroup) structure. The teachers' use of social networks affected class composition through a non-random assignment of students to teachers, based on students' previous academic achievement as well as economic status. Through a systematic analysis of the influence of these networks on key aspects of the student experience, this study highlighted the importance of teachers' social networks for teacher behaviors and in learning contexts.

Alrshedi (2012) conducted a study aimed at discovering the degree to which the faculty members at the University of Hail use social media in their teaching. The survey was used to achieve the goals of the study. The sample group was 157 faculty members, representing $10 \%$ of the faculty population. The general result, in terms of degree of social media use among the sample group, was moderate. The researcher arranged the survey's domains according to the degree of which the social media use from the most to the least as following: research and idea change, communications with colleagues, continuous learning, and subject design and methods. No significant differences were found between the sample group responses in relation to their gender or experience, except for a significant difference related to gender in the communications with colleagues domain. 
The purpose of a study conducted by Zelick (2013) was to examine faculty members' perception of Web 2.0 technologies for teaching and learning in higher education at public universities in the United States, compared to traditional classroom teaching methods. This study also examined the impact of gender, age, and employment status on faculty members' perceptions. The study found that $31.1 \%$ of faculty members described themselves as somewhat proficient with the technology, $25.4 \%$ described themselves as proficient, and $7.3 \%$ described themselves as experts. The results showed that the Web 2.0 technologies that were utilized the least were Second Life, with a mean of 1.3446, and Twitter, with a mean of 1.5367. The Web 2.0 technologies utilized the most were YouTube, with a mean of 2.6949 , and blogs, with a mean of 2.1130. The results indicated that there is a relationship between faculty members' perception of teaching college courses utilizing Web 2.0 technologies compare to teaching traditional classroom method; also, there is a relationship between faculty members' gender and their perception of Web 2.0 technologies in their courses.

A study conducted by Lie (2013) examined using Edmodo as a social networking tool to teach a course. The sample group for the study was 22 undergraduate students. Students in the course were asked to respond to a survey about how "digitized" they were. Of this sample, $94.7 \%$ own smartphones, $47.4 \%$ spend 1-2 hours a day on the Internet, $31.6 \%$ spend $2-4$ hours on the Internet, Youtube, Google, Yahoo, and social media (Facebook, Twitter, Tumblr, Edmodo) were used by the subjects, and only $5.3 \%$ read the newspaper. Moreover, the study reported that $36.8 \%$ thought that classes that use the Internet were very relevant, $31.6 \%$ thought they were extremely relevant, $26.3 \%$ thought they were moderately relevant, and $5.3 \%$ thought they were not relevant at all. The study also showed that $31.6 \%$ of subjects reported between $10-25 \%$ of their teachers using the Internet in their teaching. Another $31.6 \%$ reported between $50-80 \%$ of their teachers using the Internet. After completing the class that involved the Internet, the students' responses to the survey was as follows: $42.1 \%$ found social media extremely helpful in meeting required competences, $47.4 \%$ found it very helpful, $10.5 \%$ found it moderately helpful, and none thought it was not helpful at all. Twenty students strongly agreed that the teacher makes a good use of media and technology to achieve the required competences.

In a study conducted by Seechaliao (2014), the researcher randomly selected 31 lecturers in the Faculty of college of Education at Mahasarakham University and asked them to describe their behavior and beliefs about using social media as an educational tool in online courses in higher education. The findings of the study showed that YouTube, Facebook, and Slideshare were the most frequently used among lecturers, and that they found such social media websites easy to use because they save time and money, especially when used in online courses.

A study conducted by Gewerc, A., Montero, L., \& Lama, M. (2014) aimed to analyze the intensity and relevance of students' contributions in this collaborative framework at the University of Santiago de Compostela (Spain). The study used learning analytics tools with two types of techniques: social network analysis (SNA) and information extraction, in order to measure the intensity, centrality and relevance of collaboration among students. The results 
found and approve that: (1) The consistency and coherence between the pedagogical approach and the option of using a social network in university education; (2) A dense network with a high level of interaction, a moderate degree of centrality and a low centralization index); (3) High level of relevance to the content analyzed; (4) The usefulness of learning analytics techniques to guide teacher decision-making.

Research conducted by Bor (2014) examined three undergraduate broadcast journalism courses offered at a large research university in the western United States that attempted to integrate a social media reporting curriculum. Particular attention was focused on instructional approaches, learning outcomes, and student participation in the courses. The study results revealed that the approach to social media reporting instruction should emphasize the importance of ethics in an online environment, opportunities for career development, differences between personal and professional social media use, and the instruction of technical skills.

A study conducted by Sim, T., Naidu, D., \& Apparasam, D. (2014) looked at the implementation of Facebook in six different science, engineering and technology courses at a private university in Malaysia. The content sent through Facebook could include information about available resources that were uploaded to the learning management system, a reminder about an upcoming test or assignment deadline, an interesting article related to the class, or simply words of encouragement which enhanced the students' engagement. The results showed that students were positive in using Facebook as a tool for educational engagement. This engagement also encouraged their participation in class and enhanced their interest towards the content. Facebook features that might encourage this participation and engagement include automatic notifications of new updates, and the ease of posting information.

Echenique, Molías, and Bullen (2015) conducted a study related to the social and academic use of digital technology. The main analysis tool for this study was some in-depth, face-to-face interviews with students at the University of Catalonia (Spain). The goal of these interviews was to show how students use social media technology in their social academic lives. The results showed that the degree to which the digital technology was used by students depended on their purpose and their level of their competence, and that using such social media applications as WhatsApp were very important to students, because they facilitate their social and academic life when it comes to sharing ideas and interests.

Galant (2016) conducted a study aimed at gaining a better understanding of the use of social media technologies in pedagogy, and identifying some of the key factors that influence teachers' decisions about incorporating it. Content analysis, the so-called axes of domain analysis, and quantitative bibliometric analysis were used as research techniques. The study found that social networking sites had the highest frequency (58) of mentions in the scholarly discourse. Virtual reality (178) and/or communities (23) had the second-highest frequency ranking, with Facebook and Twitter trailing. The benefits of social media use included knowledge sharing, enhanced collaboration, increased participation and motivation, familiarity, and accrete to learning. Learning concepts such as blended learning, collaborative learning, contextual, 
assessment, blogs, browsers, collaboration, content management systems, discussion, games, hardware, messaging software, multimedia, social networking, software, video conference, and repository were all tied to the structure of social media use in the classroom and in professional discourse. Moreover, the study identified the following as factors that negatively social media use in pedagogy: too much work, hard to control, lack of support, negative perception of social media tools, and social media tools lacking in features/and or ineffective for teaching.

A study by (Simons, Ocepek, \& Barker, 2016) was conducted to discover what information should be incorporated into a formal Master's of Science in Information Studies (MSIS) program at University of Texas, according to professionals who do social media work. This study was conducted using a survey, which included 24 questions in the following categories: professional background information, everyday work, education and development, personal occupational enrichment, knowledge, and changes in the workplace. The sample group included 49 participants. The majority of the Participants agreed that social media were very importsnt, with most also believing that a course about social media platforms specifically would be useful. However, coursework should focus on developing certain themes and skills, rather than on promoting specific platforms, software tools, or information as seen by participants.

A study conducted by Fasae \& Adegbilero-Iwari (2016) investigated the use of social media by science students of public universities in Nigeria. After distributing the survey and collecting the data, it was found that among the various social media networks available, Facebook was the most recognized, used by $93.43 \%$ of participants, followed by Google (63.77\%) and Twitter (47.83\%). Two-thirds of the students used of social media daily to remain up-todate with trending events or news, and to occupy free time when they were bored. The findings also showed that Google was considered the most beneficial social media network (52.17\%) followed by Facebook (29.7\%) and Wikia (23.91\%). The leading problems encountered in the use of social media were reported as being the receiving of unwanted messages or pictures and electricity failure.Randal (2016) approached social media in a different way, conducting research that measured the concerns of faculty about online teaching, and what technology is appropriate and suitable for. The findings of this study showed that faculty who are more student-centered are more keen to collaborate with others to start teaching online.

Based on an examination of past research, the researcher for the present study believes that mathematics students at a tertiary education level can use mobile phones pedagogically, for communication purposes. The researcher feels that no previous research has attempted to investigate the use of mobile phones in teaching mathematics at general schools in Saudi Arabia. The researcher supports the hypothesis that teachers and learners may use cell phones applications for both individual and teamwork activities in the classroom setting to enhance learning and teaching.

\section{The Study}

The role of teaching has rapidly developed to support student-centered learning, especially in the rapidly changing world which introduces new technology every day. Social media platforms have entered every home on many 
mobile applications. This affects teaching methods, since students are concerned with these technologies and teachers tend to bring their attentions to classrooms. Social media has become one of the important ways by which people connect to each other. Investigating the use of social media in teaching mathematics, the extent to which teachers use this technology, and whether they believe in its importance, are the main purposes of this study.

\section{Social Media Definition}

The definition of social media definition in the Merriam-Webster dictionary is: "forms of electronic communication (as websites for social networking and microblogging) through which users create online communities to share information, ideas, personal messages, and other content (such as videos)".The researcher has accepted the Rivero (2011) definition, which defines defined social media as any tool that is similar to Facebook. Thus, in this study, social media means any tool or phone application used to connect with others, such as WhatsApp, Twitter, Facebook, YouTube, and other similar applications.

\section{Study Problem}

The problem this study addresses is the degree at which social media use in teaching mathematics at schools in the city of Tabuk, and the perception of its importance to mathematics teachers.

\section{Study Questions}

1. What is the most common type of social media application used among mathematics teachers for their teaching in Tabuk?

2. To what extent are mathematics teachers in Tabuk using social media in their teaching?

3. To what extent do the mathematics teachers perceive using social media in their teaching as important?

4. Is there a significant difference in the mathematics teachers' perceptions of the importance of using social media, based on their gender, experience, and level they teach?

\section{Study Significance}

The significance of this study is composed of many considerations: (1) No previous study has done in investigating the use of social media as a tool in teaching mathematics by teachers at Tabuk, (2) The study presents information which can draw a picture for who is responsible for developing education at the Ministry of Education regarding the use of social media in teaching, (3) The study identifies to what extent teachers are concerned with using social media in their teaching, and (4) The study results and findings contribute to the body of research in using social media in teaching.

\section{Study Instrument}

A survey was conducted in order to collect information and mathematics teachers' opinions and perceptions. It was designed by the researcher. It was comprised of two domains; the first domain related to the extent to which social media was used in teaching mathematics, and contained 19 items. The second 
domain addressed mathematics teachers' perception of the importance of social media in teaching. This domain contained 27 items. Before the survey was finalized, it was distributed to experts in order to check its validity. A pilot study was carried out to estimate the reliability of the survey. The reliability was $(\mathrm{r}=$ 0.94). The consistency of the survey was 0.84 for the first domain, and 0.96 for the second domain. After the survey had been validated, it was published on the SurveyMonkey website and sent to 633 mathematics teachers in Tabuk, who represented the sample population for the study. Only 142 mathematics teachers responded to the online survey by the deadline. Participants' responses were analyzed using SPSS program and results were organized in tables.

\section{Study Sample}

The sample of the study consisted of responses to the survey that had been sent to the study population. Table 1 classifies the individuals of the sample group according to their gender, years of experience, and the level at which they teach. Table 2 classifies the sample group according to their gender and experience.

Table 1. Study sample organized by gender, experience, and teaching level

\begin{tabular}{|c|c|c|c|c|c|c|c|}
\hline \multirow{2}{*}{ 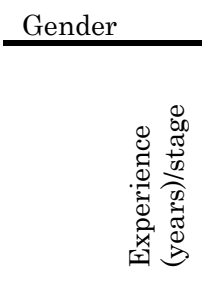 } & \multicolumn{3}{|c|}{ Male } & \multicolumn{4}{|c|}{ Female } \\
\hline & 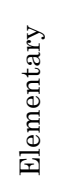 & 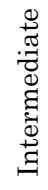 & 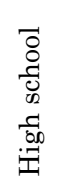 & 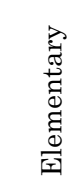 & 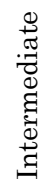 & 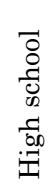 & $\begin{array}{l}\text { तु } \\
\stackrel{0}{0} \\
\stackrel{1}{1}\end{array}$ \\
\hline Less than 5 & 7 & 4 & 6 & 7 & 10 & 11 & 45 \\
\hline 5 to 10 & 7 & 15 & 3 & 6 & 2 & 5 & 38 \\
\hline $\begin{array}{l}\text { More than } \\
10\end{array}$ & 18 & 14 & 8 & 3 & 12 & 4 & 59 \\
\hline Total & 32 & 33 & 17 & 16 & 24 & 20 & 142 \\
\hline
\end{tabular}

Table 2. Study sample organized by gender and experience

\begin{tabular}{|c|c|c|c|c|c|}
\hline & & \multicolumn{3}{|c|}{ Experience (years) } & \multirow[b]{2}{*}{ Total } \\
\hline & & Less than 5 & $5-10$ & More than 5 & \\
\hline \multirow[t]{2}{*}{ Gender } & Male & 17 & 25 & 40 & 82 \\
\hline & Female & 28 & 13 & 19 & 60 \\
\hline Total & & 45 & 38 & 59 & 142 \\
\hline
\end{tabular}

\section{Study Results}

In the following section, study results will be organized by answering the study questions one by one. 


\section{Question one:}

What is the most common type of social media application used among mathematics teachers in their teaching in Tabuk?

Table 3 displays the type of social media used by teachers at Tabuk schools. These results show that Whatsapp was the most popular social media used in teaching, representing about $67 \%$ of the study sample, then Twitter (31\%). Table 4 illustrates the type of social media used according to the sample group's gender and experience. It appears that the males with more than 10 years of experience use WhatsApp as a tool in their teaching, whereas female teachers with more than 10 years of experience use it the least. The total of teachers who use WhatsApp is 95, composed of 59 males and 36 females, and representing $66.90 \%$ of the sample's total.

Table 3. Type of social media used by the study sample, grouped by gender

\begin{tabular}{|c|c|c|c|c|}
\hline \multirow{2}{*}{ Social media } & \multicolumn{3}{|c|}{ Gender } & \multirow{2}{*}{ Percentage } \\
\hline & Male & Female & Total & \\
\hline Twitter & 22 & 22 & 44 & $30.99 \%$ \\
\hline WhatsApp & 59 & 36 & 95 & $66.90 \%$ \\
\hline Facebook & 1 & 0 & 1 & $0.70 \%$ \\
\hline YouTube & 0 & 2 & 2 & $1.41 \%$ \\
\hline Total & 82 & 60 & 142 & $100 \%$ \\
\hline
\end{tabular}

Table 4. Type of social media used by the study sample, grouped by experience and gender

\begin{tabular}{cccccccc}
\hline Gender & Male & \multicolumn{5}{c}{ Female } \\
$\begin{array}{c}\text { Experienc } \\
\text { e (years) }\end{array}$ & Less than & 5 to & More than & Less than & 5 to & More than & Total \\
\hline WhatsApp & 5 & 10 & 10 & 5 & 10 & 10 & 95 \\
Twitter & 12 & 21 & 26 & 18 & 10 & 8 & 44 \\
Facebook & 1 & 4 & 14 & 9 & 3 & 10 & 1 \\
YouTube & 0 & 0 & 0 & 0 & 0 & 0 & 1 \\
Total & 17 & 25 & 40 & 1 & 0 & 19 & 142 \\
\hline
\end{tabular}

This result of The popularity of WhatsApp among mathematics teachers in Tabuk differed than the study of Naidu, D., \& Apparasam, D. (2014; Fasae \& Adegbilero-Iwari (2016); Sim, T. Y., Naidu, D., \& Apparasamy, D. (2014); and Lie (2013), where Facebook was the popular social media used. In a study by Lie (2013), found that $31.6 \%$ of teachers spent 2-4 hours per day using Youtube, Google, Yahoo, and social media (Facebook, Twitter, Tumblr, Edmodo) A study by Echenique, Molías, \& Bullen (2015) found that social media such as WhatsApp were used by students due to their belief that these tools facilitate learning. However, no previous study found WhatsApp to be the most used 
social media application, except this study. This can be interpreted as a spread of this application among users in Saudi, and its ease of use in the society sense it is a tool for communication and available in e-stores for free download.

Table 4 illustrates that Facebook and YouTube were used by only three teachers in the study sample.

\section{Question 2:}

To what extent do mathematics teachers in Tabuk use social media in their teaching?

In accordance with the scales used in this kind of study, the researcher accepted the following scale, using the mean of participants' responses for items in the survey in order to interpret the participants' responses in both domains. Table 5 illustrates the mean ranges to determine the status social media use, and to determine the teachers' perception of the importance of using social media in their teaching.

Table 5. The scale used in this study

\begin{tabular}{cc|cc}
\hline $\begin{array}{c}\text { Interpretation of Domain 1: } \\
\text { Social media usage }\end{array}$ & \multicolumn{3}{|c}{ Interpretation of Domain 2: } \\
The importance of social media \\
$1-1.80 \quad$ Never existed & $1-2.80$ & Unimportant \\
$1.81-2.60$ & Rarely & $1.81-2.60$ & Fairly important \\
$2.61-3.40$ & Sometimes & $2.61-3.40$ & Somewhat important \\
$3.41-4.20$ & Mostly & $3.41-4.20$ & Important \\
$4.21-5$ & Always & $4.21-5$ & Very important \\
\hline
\end{tabular}

To interpret Domain 1 results, the following scale was used: (1) a mean of less than 1.81 were classified "never", (2) means ranging from 1.81-2.60 were classified as "rarely"; (3) means ranging from 2.61-3.40 were classified as "sometimes"; (4) means ranging from 3.41-4.20 were classified as " mostly"; and (5) means from $4.21^{-5}$ were classified as "always".

To interpret Domain 2 results, the following scale was used: (1) means of less than 1.81 were considered "unimportant", (2) means ranging from 1.81-2.60 were considered "fairly important"; (3) means ranging from 2.61-3.40 were considered "somewhat important"; (4) means ranging from 3.41-4.20 were considered "important"; and (5) means from 4.21-5 were considered "very important", as illustrated in Table 5. 
Table 6. Domain 1: The use of social media among the sample group

\begin{tabular}{|c|c|c|c|c|c|}
\hline & Items & & Mean & $\begin{array}{c}\text { Std. } \\
\text { deviation }\end{array}$ & $\begin{array}{c}\text { Degree of } \\
\text { use }\end{array}$ \\
\hline 1. & $\begin{array}{l}\text { I use social media as one of my methods in teaching } \\
\text { mathematics }\end{array}$ & 142 & 2.65 & .817 & Sometimes \\
\hline 2. & $\begin{array}{l}\text { I give students my social media contact information at the } \\
\text { beginning of the semester }\end{array}$ & 142 & 2.55 & .919 & Sometimes \\
\hline 3. & I encourage students to contact me using social media & 142 & 2.72 & .918 & 3 Sometimes \\
\hline 4. & I encourage students to form groups on social media & 142 & 2.77 & 1.074 & Sometimes \\
\hline 5. & $\begin{array}{l}\text { I give students an idea about the necessary apps for using } \\
\text { social media }\end{array}$ & 142 & 2.54 & .872 & Rarely \\
\hline 6. & $\begin{array}{l}\text { I recognize students' academic improvement through the use } \\
\text { of social media }\end{array}$ & 142 & 2.63 & .830 & Sometimes \\
\hline 7. & $\begin{array}{l}\text { By the use of social media, I implement the concept of } \\
\text { cooperative learning }\end{array}$ & 142 & 2.81 & 1.058 & 3 Sometimes \\
\hline 8. & $\begin{array}{l}\text { I deliver the content of the course to my students through } \\
\text { social media }\end{array}$ & 142 & 2.66 & .937 & Sometimes \\
\hline 9. & $\begin{array}{l}\text { I give students a chance to cooperate in learning through the } \\
\text { use of social media }\end{array}$ & 142 & 2.66 & .929 & Sometimes \\
\hline 10. & I solve students' learning problems through social media & 142 & 2.63 & .935 & Sometimes \\
\hline 11. & I teach some parts of the math course using social media & 142 & 2.72 & .918 & Sometimes \\
\hline 12. & $\begin{array}{l}\text { I give students extra-curricular activities assigned through } \\
\text { social media }\end{array}$ & 142 & 2.65 & .859 & Sometimes \\
\hline 13. & $\begin{array}{l}\text { I assign students to groups in social media to discuss and } \\
\text { solve math problems }\end{array}$ & 142 & 2.69 & .916 & Sometimes \\
\hline 14. & $\begin{array}{l}\text { I prepare quizzes for students and conduct them through } \\
\text { social media }\end{array}$ & 142 & 2.86 & 1.001 & Sometimes \\
\hline 15. & I design courses using social media & 142 & 2.65 & .954 & Sometimes \\
\hline 16. & $\begin{array}{l}\text { I train students to manage the content of the course and have } \\
\text { discussions through social media }\end{array}$ & 142 & 2.73 & .892 & Sometimes \\
\hline 17. & Social media gives me other ways of teaching math & 142 & 2.60 & .931 & Sometimes \\
\hline 18. & $\begin{array}{l}\text { I give students the chance to search for information using } \\
\text { social media }\end{array}$ & 142 & 2.56 & 1.014 & Rarely \\
\hline & $\begin{array}{l}\text { I use social media in exchanging mathematics teaching } \\
\text { strategies with my colleagues }\end{array}$ & 142 & 2.72 & .941 & Sometimes \\
\hline
\end{tabular}

As seen in Table 6, most of the items are classified as occurring "sometimes", since their mean values are less than (3.41). This indicates that teachers' use of social media is not organized but randomly used by some teachers to clarify concepts for students, or to contact students and provide information. In Table 6, it appears that teachers rarely give students information about the necessary applications for social media and rarely give them chance to search for information using social media. Those two items (5 and 18) support the argument that there is no trend of using social media as a tool for helping students learn, since teachers are uncertain about using social media; this concern was reported by Gammon \& McGranahan (2015). Teachers may feel obligated to use social media due to the currently developed mobile devices that use multiple social media apps. Those findings are somewhat similar to studies by (Alrshedi, 2012; Zelick, 2013; Kim, 2011; Gewerc, A., Montero, L., \& Lama, M., 2014; and Randall, 2016). 


\section{Question 3:}

To what extent do the mathematics teachers perceive using social media in their teaching as important?

Table 7. Domain 2: The importance of using social media in teaching

\begin{tabular}{|c|c|c|c|c|c|}
\hline \multicolumn{2}{|r|}{ Item } & \multicolumn{3}{|c|}{$\begin{array}{c}\text { Std. } \\
\text { N Mean deviation } \\
\end{array}$} & Its importance \\
\hline 1. & I use social media in teaching math & 142 & 3.55 & 1.076 & $\overline{\text { Important }}$ \\
\hline 2. & $\begin{array}{l}\text { I give students my social media contact information at } \\
\text { the beginning of the semester }\end{array}$ & $\mathrm{t} 142$ & 3.44 & 1.194 & Important \\
\hline 3. & $\begin{array}{l}\text { I encourage students to communicate through social } \\
\text { media more than other ways }\end{array}$ & 142 & 3.56 & 1.139 & Important \\
\hline 4. & $\begin{array}{l}\text { Social media makes it easy for students to } \\
\text { communicate within groups }\end{array}$ & 142 & 3.48 & 1.115 & Important \\
\hline 5. & $\begin{array}{l}\text { I give students an idea about the apps necessary for } \\
\text { using social media }\end{array}$ & 142 & 3.48 & 1.248 & Important \\
\hline 6. & $\begin{array}{l}\text { Some students advance because of their use of social } \\
\text { media apps }\end{array}$ & 142 & 3.52 & 1.189 & Important \\
\hline 7. & $\begin{array}{l}\text { Social media is important for students' learning } \\
\text { advancement }\end{array}$ & 142 & 3.50 & 1.147 & Important \\
\hline 8. & $\begin{array}{l}\text { I encourage students to seek credibility when they use } \\
\text { social media }\end{array}$ & e142 & 3.44 & 1.211 & Important \\
\hline 9. & Using social media encourage students' learning & 142 & 3.54 & 1.165 & Important \\
\hline 10. & $\begin{array}{l}\text { Using social media encourages students' collaborative } \\
\text { methods and skills. }\end{array}$ & 142 & 3.59 & 1.168 & Important \\
\hline 11. & $\begin{array}{l}\text { Social media helps students by delivering the content } \\
\text { of the course }\end{array}$ & 142 & 3.80 & .993 & Important \\
\hline 12. & $\begin{array}{l}\text { Social media helps facilitate presentation of } \\
\text { information }\end{array}$ & 142 & 3.58 & 1.186 & Important \\
\hline 13. & $\begin{array}{l}\text { Social media helps in considering individual } \\
\text { differences among students }\end{array}$ & 142 & 3.73 & 1.065 & Important \\
\hline 14. & $\begin{array}{l}\text { Social media gives students the chance to cooperate in } \\
\text { learning }\end{array}$ & a142 & 3.49 & 1.189 & Important \\
\hline 15. & $\begin{array}{l}\text { Social media gives me the chance to solve students' } \\
\text { problems }\end{array}$ & 142 & 3.31 & 1.168 & $\begin{array}{l}\text { Somewhat } \\
\text { important }\end{array}$ \\
\hline 16. & $\begin{array}{l}\text { I teach the content of some courses through social } \\
\text { media }\end{array}$ & 142 & 3.53 & 1.128 & Important \\
\hline 17. & $\begin{array}{l}\text { I give students extracurricular activities through } \\
\text { social media }\end{array}$ & 142 & 3.42 & 1.119 & Important \\
\hline 18. & $\begin{array}{l}\text { Assigning students to groups in social media helps } \\
\text { them discuss and solve math problems }\end{array}$ & 142 & 3.49 & 1.141 & Important \\
\hline 19. & $\begin{array}{l}\text { Social media helps me in preparing quizzes and } \\
\text { conducting them through social media }\end{array}$ & 142 & 3.56 & 1.108 & Important \\
\hline 20. & I designed the math course using social media & 142 & 3.54 & 1.001 & Important \\
\hline 21. & $\begin{array}{l}\text { Using social media helps students gain more } \\
\text { confidence }\end{array}$ & 142 & 3.44 & 1.170 & Important \\
\hline 22. & $\begin{array}{l}\text { Using social media gives students important life } \\
\text { experiences }\end{array}$ & 142 & 3.49 & 1.103 & Important \\
\hline 23. & $\begin{array}{l}\text { Using social media equips students with the skills for } \\
\text { discussion and debate }\end{array}$ & 142 & 3.55 & 1.176 & Important \\
\hline 24. & $\begin{array}{l}\text { Social media equips students with the skill of self- } \\
\text { learning }\end{array}$ & 142 & 3.44 & 1.176 & Important \\
\hline 25. & $\begin{array}{l}\text { Social media helps in creating a variety in math- } \\
\text { teaching methods }\end{array}$ & 142 & 3.44 & 1.194 & Important \\
\hline 26. & Social media pushes students to learn & 142 & 3.48 & 1.115 & Important \\
\hline 27. & Social media helps students gain social skills & 142 & 3.51 & 1.116 & Important \\
\hline
\end{tabular}


As seen in Table 7, most items are recognized as "important", as classified in Table 5. Only item number (34) is classified as "somewhat important". The mean range is from $3.42-3.80$.

Item number (34) says: "Social media gives me the chance to solve students' problems". It may be impossible for teachers who participate in this study to know how social media apps will help students; however, teachers are aware of the importance of using social media in their teaching and believe it makes a difference. The total mean of this domain reports is 3.52 , which shows that the teachers are aware of the importance of using social media in their teaching since the communicational apps advanced used recently. These findings are somewhat similar to the findings of (Lubega et al. ,2004; Wei and Chen, 2006; Inagaki et al., 2004; Traxler et al., 2005; Genossar et al., 2008; Seechaliao, 2014; Alrshedi, 2012; Galant, 2016; Zelick, 2013; Lie, 2013; Gewerc, A., Montero, L., \& Lama, M., 2014; Simons, Ocepek, \& Barker, 2016; Sim, T., Naidu, D. \& Apparasam, D., 2014; Lubega et al., 2004; Wei \& Chen, 2006; Inagaki et al., 2004; Traxler et al., 2005; Genossar et al., 2008; Seechaliao , 2014; and Echenique, Molías, \& Bullen, 2015). However, these findings contradict those of a study by Kelli K. (2014), who found that community college teachers perceived online media as less important than what was found in this study.

\section{Question 4:}

Is there a significant difference in the mathematics teachers' perceptions of the importance of using social media, based on their gender, experience, and level they teach?

In order to answer Question 4, a three-way Anova test was conducted. The answer to this question was composed of two sections, according to the two survey domains.

First, the research tested whether there was a difference in the means of the participants' responses in the first domain, which related to gender, experience, and level at which they teach. Table 8 illustrates the mean of sample's response to the use of social media in teaching according to the gender, experience, and stage level. The total mean was 2.67. The smallest mean was reported as 2.26, representing male elementary school teachers with less than 5 years of experience. The largest mean reported was 2.96 , for female high school teachers with more than ten years of experience. It appeared that those who had more than 5 years of high school teaching experience had a higher mean than those who taught in elementary schools; however, we could not determine any significant differences until after running a three-way Anova test, the results of which are represented in Table 9. 
Table 8. The subjects' responses' means according to gender, experience, and level taught for Domain 1

\begin{tabular}{|c|c|c|c|c|c|}
\hline Gender & Experience & Level taught & Mean & $\begin{array}{c}\text { Std. } \\
\text { deviation }\end{array}$ & $\mathrm{N}$ \\
\hline \multirow[t]{9}{*}{ Male } & \multirow{3}{*}{$\begin{array}{l}\text { Less than } 5 \\
\text { years }\end{array}$} & Elementary & 2.2556 & .47019 & 7 \\
\hline & & Intermediate & 2.6053 & .51119 & 4 \\
\hline & & High School & 2.5702 & .26087 & 6 \\
\hline & \multirow[t]{3}{*}{$5-10$} & Elementary & 2.4436 & .40182 & 7 \\
\hline & & Medium & 2.5474 & .52473 & 15 \\
\hline & & High School & 2.9298 & .24309 & 3 \\
\hline & \multirow[t]{3}{*}{ More than 10} & Elementary & 2.3655 & .42890 & 18 \\
\hline & & Intermediate & 2.7256 & .35945 & 14 \\
\hline & & High School & 2.7434 & .40421 & 8 \\
\hline \multirow[t]{9}{*}{ Female } & \multirow{3}{*}{$\begin{array}{l}\text { Less than } 5 \\
\text { years }\end{array}$} & Elementary & 2.8947 & .17456 & 7 \\
\hline & & Intermediate & 2.8684 & .37484 & 10 \\
\hline & & High School & 2.7990 & .44337 & 11 \\
\hline & \multirow[t]{3}{*}{$5-10$} & Elementary & 2.6579 & .71140 & 6 \\
\hline & & Intermediate & 3.3158 & .07443 & 2 \\
\hline & & High School & 2.8947 & .57535 & 5 \\
\hline & \multirow[t]{3}{*}{ More than 10} & Elementary & 2.7368 & .36842 & 3 \\
\hline & & Intermediate & 2.8596 & .50199 & 12 \\
\hline & & High School & 2.9605 & .67316 & 4 \\
\hline
\end{tabular}

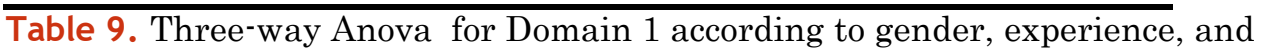
level taught

\begin{tabular}{llllll}
\hline Source & $\begin{array}{l}\text { Type III sum of } \\
\text { squares }\end{array}$ & Df & Mean square & F & Sig. \\
\hline Gender & 2.436 & 1 & 2.436 & 12.073 & .001 \\
Experience & .281 & 2 & .140 & .695 & .501 \\
Level taught & 1.570 & 2 & .785 & 3.891 & .023 \\
Gender*experience & .092 & 2 & .046 & .229 & .796 \\
Gender*level taught & .369 & 2 & .185 & .915 & .403 \\
Experience*level taught & .274 & 4 & .069 & .340 & .851 \\
Gender*experience*level & .795 & 4 & .199 & .984 & .419 \\
taught & 1046.288 & 142 & & & \\
Total & & & & & \\
\hline
\end{tabular}

Male mean $=2.576$; female mean $=2.888$

Table 9 illustrates the three-way Anova test for Domain 1 means of participants' responses according to their gender, experience, and level at which they teach. The three-way Anova analysis shows that there is a significant difference between teachers in their use of social media related to gender, with a mean of 2.89 for female teachers, versus 2.58 for male teachers. The three-way 
Anova analysis reported no significant difference among the participants' use of social media related to either their experience or the level at which they teach.

Domain 2: The importance of using social media in teaching

Table 10 illustrates the means of participants' responses to Domain 2, according to their gender, experience, and level at which they teach.

Table 10. Means of the subjects' views of social media importance according to gender, experience, and level taught variables for Domain 2

\begin{tabular}{|c|c|c|c|c|c|}
\hline Gender & Experience & $\begin{array}{l}\text { Level } \\
\text { taught }\end{array}$ & Mean & $\begin{array}{c}\text { Std. } \\
\text { deviation }\end{array}$ & $\mathrm{N}$ \\
\hline \multirow[t]{9}{*}{ Male } & 1 & 1 & 3.0053 & .65992 & 7 \\
\hline & & 2 & 3.8056 & .87404 & 4 \\
\hline & & 3 & 3.2346 & .52466 & 6 \\
\hline & 2 & 1 & 2.7566 & 41949 & 7 \\
\hline & & 2 & 2.9284 & .55032 & 15 \\
\hline & & 3 & 3.0370 & .32075 & 3 \\
\hline & 3 & 1 & 3.1152 & .84332 & 18 \\
\hline & & 2 & 3.0265 & .73422 & 14 \\
\hline & & 3 & 2.9074 & 65868 & 8 \\
\hline \multirow[t]{9}{*}{ Female } & 1 & 1 & 4.1852 & .33675 & 7 \\
\hline & & 2 & 4.2519 & .37601 & 10 \\
\hline & & 3 & 3.9630 & .39718 & 11 \\
\hline & 2 & 1 & 4.0988 & .36339 & 6 \\
\hline & & 2 & 4.4815 & .31427 & 2 \\
\hline & & 3 & 4.2667 & .23917 & 5 \\
\hline & 3 & 1 & 4.0741 & .74351 & 3 \\
\hline & & 2 & 4.2500 & .37310 & 12 \\
\hline & & 3 & 3.9630 & .25838 & 4 \\
\hline
\end{tabular}

As seen in Table 12, the largest mean was reported as 4.48 , which represented female teachers at intermediate schools 5-10 years of experience. The smallest mean reported was 3.01, which represented male teachers at elementary schools with less than 5 years of experience. Other means were found to be between 3.01 and 4.48. In order to determine whether there are significant differences among the means related to gender, experience, and level taught, a three-way Anova test was conducted and is reported in Table 12. 
Table 11. Three-way Anova test for Domain 2 according to gender, experience, and level taught

\begin{tabular}{lrrrrr}
\hline & Type III sum of & & & & \\
Source & squares & Df & Mean square & F & Sig. \\
\hline Gender & 29.312 & 1 & 29.312 & 88.064 & .000 \\
Experience & .737 & 2 & .369 & 1.108 & .334 \\
Level taught & 1.312 & 2 & .656 & 1.970 & .144 \\
Gender*experience & $t 1.387$ & 2 & .694 & 2.084 & .129 \\
Gender*level taught & .103 & 2 & .051 & .154 & .857 \\
Experience*level taugh & .836 & 4 & .209 & .628 & .643 \\
Gender*experience*level taught & .990 & 4 & .247 & .743 & .564 \\
Total & 1842.737 & 142 & & & \\
a. $\mathrm{R}$ squared=.535 (Adjusted R squared=.471) & & & & & \\
\hline
\end{tabular}

Male $=3.094 ;$ female $=4.274$

Table 11 illustrates significant differences among participants' means in perception of the importance of social media related to gender favoring the female teachers. the mean of female teachers was 4.27 , while the mean of male teachers was 3.09. As seen in Table 12, there were no differences among participants' means related to either experience or level taught. The findings of this study were similar to a study by Zelick (2013), and contradicted a study by Alrshedi (2012).

\section{Conclusion}

The current study findings revealed that the most-used social media application among mathematics teachers is WhatsApp, which was used by $66.90 \%$ of the participants in this study. The use of social media in teaching mathematics was classified as "sometimes" in all items in Domain 1, except for two items classified as "rarely": these were teachers giving students information about social media apps, and teachers instructing students how to search for information using these apps. Teachers precieved the use of social media in the classroom as important. Differences among participants' means in Domain 1 were related to gender, experience, and teaching level, as tested by the threeway Anova analysis. A a significant difference related to gender was found, and indicated that more female teachers favor social media. Mathematics teachers believe in the importance of using social media in their teaching. Teachers' perception of the importance of using social media also differed significantly related to gender, again with female teachers ranking it more favorably; however; no differences were reported related to experience or level taught in the perception of the importance of using social media.

\section{Recommendations and implementation}

Since the study found that the use of social media by mathematics teacher occurred to be moderate with no attend purpose of using, it is important for educators and teachers to consider its ability to shift teaching pedagogy. Harris,. et al (2016) conclude that "the flipped classroom model is one model educators are experimenting with to address the needs of learners and expand students' capabilities for learning more efficiently and effectively in a time when lifelong 
learning is crucial to individuals and society (331)." More over, Positive perceptions and beliefs on the use of social media in the teaching and learning process will be the important principle that will guide the development of using social media in teachers' instruction in the future. That was found in study of Goya (2014) which revealed the impact of a teacher study group on six community college instructors' beliefs about teaching and the use of social media as a teaching tool.

Since mathematics teachers believe in the benefits of using social media, they will involve these tools in their instruction, content design, and student assessment. The researcher recommend mathematics teachers, in particular, to consider instruction that can help students understand math concepts, especially that bring the students enthusiasm to learn and related to their real lives like using social media. Social media has become a popular communication tool, and is familiar to students, and mathematics teachers should consider these factors. Also, the focus of teaching is shifting from the role of the teacher to the role of the students, moving toward student-centered learning which should be taking into account. Moreover, in terms of teacher education programs, the new shift of using social media in their programs to prepare teachers should be considered. Also, teachers who at service should be trained when and how to use the social media as a tool for teaching and learning which may be unconsidered in many professional development programs. Adam (2015)reported that the PD sessions were not concentrate on enhancing teachers educators' technological and pedagogical practices in terms of using advanced technology and implement them in teaching students.

Collaboration and working in groups should be emphasized by teachers in their teaching to enhance students' engagement. Finally, researchers should concentrate on the mobile applications and software that may help students learning mathematics and understanding its concepts easily.

\section{Disclosure statement}

No potential conflict of interest was reported by the authors.

\section{Notes on contributors}

Abdullah Suliman Albalawi is a PhD, Associate Professor of Mathematics Education Department of Curriculum and Instruction, University of Tabuk, Saudi Arabia

\section{References}

Adam, A. (2015). Professional development for enhancing technology-integrated pedagogical practice: An ethnographic study in a Maldivian teacher education context. The Maldives National Journal of Research, 3(1), 7-28

Alenezi, Y., \& Almejadi, H. (2013). Female students Use of Social Media (facebook, and Twitter) in Mathematics at Basic Education College in Kuwait. Assiut University journal, 29(2), 351396

Al-Mukhaini, E., Al-Qayoudhi, W., \& Al-Badi, A. (2014). Adoption of social networking in education: A study of the use of social networks by higher education students in oman. Journal of International Education Research, 10(2), 143. Retrieved from https://search.proquest.com/docview/1516960787?accountid=142908 
Alrshedi, Sultan.(2012). The degree of use of the members of Faculty at the University of Hail to the social Networking Sites in the Educational Process. A master thesis. Yarmouk University, Jordan. Retrived from http://search.mandumah.com/Record/739365.

Arieanna (2007, August 21). Educational benefits of social networking. Education week.

Attewell, P., \&Winston, H.(2003). Children of the digital divide. In Attewell \&N.M. Seel (Eds), Disadvantaged teen and computer technologies,(pp.117-136).Munster, Germeny: Waxmann.

Baran, E. (2014). A Review of Research on Mobile Learning in Teacher Education. Educational Technology \& Society, 17 (4), 17-32.

Baird, E.E., \& Fisher, M. (2006). Neomillenial user experience design strategies: Utilizing social networking media to support "always on" learning styles. Journal of educational technology systems, 34(1), 5-32.

Bor, Stephanie(2014). Teaching Social Media Journalism: Challenges and Opportunities for Future Curriculum Design. Journalism \& Mass Communication Educator, 2014, 69(3), 243 -255

Boyle, Raymond. (2013). Media Convergence: Networked Digital Media in Everyday Life. Media, culture \& society, 35(5), 666

Cao, Y., \& Hong, P. (2011). Antecedents and consequences of social media utilization in college teaching: A proposed model with mixed-methods investigation. On the Horizon, 19(4), 297306. doi:http://dx.doi.org/10.1108/10748121111179420

Dawley, L. (2009). Social network knowledge construction: Emerging virtual world pedagogy. On the Horizon, 17(2), 109-121. doi:http://dx.doi.org/10.1108/10748120910965494

Downes, S. (2010). New technology supporting informal learning. Journal of Emerging Technologies in Web Intelligence, 2(1), 27-33.

Echenique, E. G., Molías, L. M., \& Bullen, M. (2015). Students in higher education: Social and academic uses of digital technology/El estudiante en la educación superior: Usos académicos y sociales de la tecnología digital. RUSC, 12(1), 25-37. Retrieved from http://search.proquest.com/docview/1649686328?accountid=142908

Elkaseh, A. M., Wong, K. W., \& Fung, C. C. (2016). Perceived ease of use and perceived usefulness of social media for e-learning in libyan higher education: A structural equation modeling analysis. International Journal of Information and Education Technology, 6(3), 192-199. doi:http://dx.doi.org/10.7763/IJIET.2016.V6.683

Fasae, J. K., \& Adegbilero-Iwari, I. (2016). Use of social media by science students in public universities in southwest Nigeria. The Electronic Library, 34(2), 213-222. Retrieved from https://search.proquest.com/docview/1775311638?accountid=142908

Galante, Anne T. (2016) Social Media Use in Classroom Teaching: A Facet-Based Discourse Analysis of Key Factors Influencing Pedagogy. Doctorate Dissertation, Long Island University. MI 48106 - 1346.

Gammon, M. A., \& McGranahan, C. (2015). Theory through application: A study in the use of social media for teaching. The Journal of Faculty Development, 29(2), 23-32. Retrieved from https://search.proquest.com/docview/1776597620?accountid=142908

Genossar, S., Botzer, G., \& Yerushalmy, M. (2008). Learning with mobile technology: A case study with students in mathematics education. International Journal of Emerging Technologies in Learning, 4(1), 23-28.

Gewerc, A., Montero, L., \& Lama, M. (2014). Collaboration and social networking in higher Education/ Colaboracióny redes sociales en la enseñanza universitaria. Comunicar, 21(42), 55-63. Retrieved from: https://search.proquest.com/docview/1476490885?accountid=142908

Goya, K. K. (2014). The impact of a teacher study group on teacher beliefs about teaching and social media (Order No. 3648540). Available from ProQuest Dissertations \& Theses Global. (1651539024). Retrieved from http://search.proquest.com/docview/1651539024?accountid=142908 
Hagler, B. E. (2013). Value of Social Media in Today's Classroom. The Journal of Research in Business Education, 55(1), 14-23. Retrieved from https://search.proquest.com/docview/1543749636? accountid=142908

Hsueh, S. (2011). Challenges of Adopting Web 2.0 and Mobile 2.0 for Language Learning. In B. Facer, \& M. Abdous (Eds.), Academic Podcasting and Mobile Assisted Language Learning: Applications and Outcomes (pp. 70-91). doi:10.4018/978-1-60960-141-6.ch005 http://www.igi-global.com/chapter/challenges-adopting-web-mobilelanguage/50671

Inagaki, T., Kobayashi, Y., \& Nakagawa, H. (2004). Attitude survey for pupils about using mobileular phones in classrooms. In L. Cantoni \& C. McLoughlin (Eds.), Proceedings of World Conference on Educational Multimedia, Hypermedia and Telecommunications 2004 (pp. 1059-1065). Chesapeake, VA:AACE.

Jankauskaite, D. (2015). Social media as a tool for improving teaching and learning experience. Signum Temporis, 7(1), 54-59. doi:http://dx.doi.org/10.1515/sigtem-2016-0008

Jee, H., Park, J.\& Wanta, W. (2011). Exploring Factors in the Hostile Media Perception: Partisanship, Electoral Engagement, and Media Use Patterns. Journalism \& Mass Communication Quarterly, 88(1). 40-54.

Kim, C. M. (2011). The effect of teachers' social networks on teaching practices and class composition (Order No. 3452840). Available from Education Database. (867093530). Retrieved from https://search.proquest.com/docview/867093530?accountid=142908

Kukulska-Hulme, A., Traxler, J.,\& Pettit, J. (2007). Designed and user-generated activity in the mobile age. Journal of Learning Design, 2(1), 52-65.

Lie. Anita (2013). Social Media In A Content Course for The Digital Natives, TEFLIN Journal, Volume 24, Number 1, January 2013

Lubega, J. T., McCrindle, R. J., Williams, S. A., Armitage, U. \& Clements, I. (2004): Use of Mobile Phones in Higher Education: In: Cantoni, L. \& Mc Loughlin, C. (Hrsg.) EdMedia 2004, Lugano, Switzerland, S. 3951-3956.

Merriam-Webster Dictionary, retrieved 12/28/2016. https://www.merriam webster.com/dictionary/social\%20media

Okoro, E. (2012). Integrating Social Media Technologies In Higher Education: Costs-Benefits Analysis. Journal of International Education Research - Third Quarter 201; 8, 3.

Randal, John H. (2016). Stages of Faculty Concern About Teaching Online: Relationship Between Faculty Teaching Methods and Technology Use in Teaching. Pepperdine University Graduate School of Education and Psychology. Pepperdine University. Dissertation and Thesis. ProQuest Number: 10139810. MI 48106 -- 1346

Rivero, Victor. 2011. "We're talking social media in education." Internet@ Schools 18 (3) : 12-15. May/Jun2011, Vol. 18 Issue 3, p12.

Santovec, M.L. (2006, March). Using online networking to engage and retain students. Recruitment and retention in higher education, 20 (3), 1, 3, 75 . Academic Search Premiere.

Seechaliao, T.(2014). Lecturers' Behaviors And Beliefs About The Use Of Social Media In Higher Education: A Study At Mahasarakham University In Thailand. Journal of International Education Research - Second Quarter 2014 Volume 10, Number 2.

Siemens, G. (2005). Connectivism: A learning theory for the digital age. International Journal of Instructional Technology and Distance Learning, 2(1), 3-10.

Sim, T. Y., Naidu, D., \& Apparasamy, D. (2014). Improving students engagement through social media a case study of a private university in malaysia using facebook. International Journal of e-Education, e-Business, e-Management and e-Learning, 4(6), 396-409. doi:http://dx.doi.org/10.17706/IJEEEE.2014.V4.354

Simons , R., Ocepek, O.\&Barker, J.(2016). Teaching Tweeting: Recommendations for Teaching Social Media Work in LIS and MSIS Programs. Journal of Education for Library and Information Science, 57:1, 21-30.

Traxler, J., \& Kukulska-Hulme, A. (2005). Evaluating mobile learning: Reflections on current practice. Mlearn 2005: 4th world conference on mLearning, Cape Town, South Africa, 
October 25ñ28 [Online]. Retrieved February 28, 2007, from http://www.mlearn.org.za/CD/BOA_p.65.pdf

Wei , F.-S., \& Chen, G.-D. (2006). Collaborative mentor support in a learning context using a ubiquitous discussion forum to facilitate knowledge sharing for lifelong learning. British Journal of Educational Technology, 37(6), 917-935.

Zelick, S. A. (2013). The perception of web 2.0 technologies on teaching and learning in higher education: A case study(Order No. 3564331). Available from ProQuest Dissertations \& $\begin{array}{llll}\text { Theses } & \text { Global. } & \text { (1412660218). } & \text { Retrieved }\end{array}$ https://search.proquest.com/docview/1412660218?accountid=142908 